\title{
Penggunaan Alat Bantu Pembelajaran Untuk Meningkatkan Hasil Belajar Pointing Petanque Pada Peserta Didik Kelas V SDN Teguhan 1 Ngawi
}

\author{
Ardi Widyastomo \\ Program Studi Pendidikan Jasmani, Kesehatan dan Rekreasi \\ STKIP Modern Ngawi, arditomo271@gmail.com \\ Salman Al Faresi \\ Program Studi Pendidikan Jasmani, Kesehatan dan Rekreasi \\ STKIP Modern Ngawi, salmanalfaresi970@ gmail.com
}

\begin{abstract}
ABSTRAK
Tujuan penelitian ini adalah meningkatkan hasil belajar Pointing Petanque peserta didik kelas V SDN Teguhan 1 Ngawi Tahun Ajaran 2019. Penelitian ini merupakan Penelitian Tindakan Kelas (PTK). Penelitian dilaksanakan menggunakan 1 siklus. Subjek penelitian ini adalah peserta didik kelas V SDN Teguhan 1 Ngawi Tahun Ajaran 2019 berjumlah 44 peserta didik. Sumber data adalah peserta didik, guru beserta peneliti. Teknik pengumpulan data adalah dengan observasi dan tes. Validitas data dengan menggunaka teknik triangulasi data. Teknik analisis data menggunakan teknik kualitatif dengan menggunakan teknik presentase dalam proses pembelajaran. Dalam siklus 1 terjadi kecapaian yang bagus untuk penelitian tindakan kelas ini. Hasil penelitian menunjukkan dari kondisi awal ke siklus I supaya terjadi ketuntasan yang baik. Ketercapaian ketuntasan hasil belajar passing bawah siklus I sebesar 48,48\% atau 16 dari 33 peserta didik. Kesimpulan penelitian ini mengacu dengan alat bantu pembelajaran dapat meningkatkan hasil belajar Pointing Petanque peserta didik kelas V SDN Teguhan 1 Ngawi Tahun Ajaran 2019.
\end{abstract}

Kata kunci: Hasil belajar, Pointing petanque, alat bantu pembelajaran

\section{PENDAHULUAN}

Pendidikan jasmani dimulai dari sekolah dasar, untuk mngetahui bakat seorang yang baik maka di perlukan pembinaan yang baik dalam pngelolaan pembinaan. Didalam hal pngetahuan petanque.imni salah satu olahraga baru yang bisa berkembang dengan sangat pesat dan harus di dukung oleh beberapa pihak..pihak yang mendung harus semaksimal mungkin.

Petanque adalah olahraga baru, didalam cabang ini ada beberapa teknik yaitu teknik pointing dan teknik shooting.semua harus dipahami demi kebaikan dan kemajuan petanque yang ada dikabupaten ngawi terutama di SDN Teguhan 1 Ngawi Tahun Ajaran 2019.Dalam hal ini petanque adalah olahraga yang bisa dimaenkan siapapun dan cukup mmenjadi olahraga yang sangat menarik terutama dikalanmngan anak anak SD. Petanque dikabupaten ngawi sangatlah bagus untuk perbaikan kualitas anak anak dalam mngembangkan sebuah olahraga yang sangat baik dan memasyarakat. Penelitan ini memfokuskan untuk mngembangkan sebuah cara supaya anak lebih tertarik dan bisa menyenangkan. Dalam hal inio harus dimulai dari niat dan semangat dari yang lainnya. Penelitian ini harus selalu dalam jalurnya dan rool nya. Anak didik harus selalu aktif dalam melakukan olahra petanque ini

\section{KAJIAN PUSTAKA \\ Daya Tarik Permainan Petanque \\ Dalam melakukan kegiaatan petanque diperlukann kesungguhan, suatu perusahaan industri alat-alat olahraga agar dibuatkan alat olahraga sebagai percobaan. Setelah bola}


dengan spesifikasi khusus tercipta, tidak lama kemudian permainan tersebut didemontrasikan didepan para ahli pendidikan jasmani, pada suatu konferensi di springfield collegge, springfield masachusettes. Atas anjuran james dalam sebuah kegiatan secara resmi yang dilakukan dengan baik dan terprogram setelah melihat bahwa dasar yang dipergunakan dalam minonate adalah mem-volley bola (yakni memukul-mukul bola hilir mudik diudara), olahraga ini kemudian di beri nama volley ball. Pada tahun 1905 peraturan-peraturan bolavoli mulai diciptakan, dan seiring perkembangan zaman terjadi fariasi perkembangan Peraturan permainan petanque uini seharusnya bisa dapat meningkatkan sebuah motivasi yang sangat bermanfaat bagi seluru terutama pada anak anak.

Menurut Nuril Ahmadi (2007:22) "Passing merupakan upaya seorang pemain dengan menggunakan suatu teknik tertentu untuk mengoperkan bola yang dimainkannya kepada teman seregunya untuk dimainkan di lapangan sendiri". Passing bawah merupakan cara memainkan bola dengan menggunakan kedua lengan yang saling bertautan atau dengan satu lengan.

Menurut Sunardi dan Deddy Whinata K (2013: 26) beberapa kesalahan yang biasanya dilakukan pada saat melakukan Petanque adalah :

1. Kurang memperhatikan servis lawan.

2. Kurang cepat mengikuti arah jatuhnya bola.

3. Melakukan passing pada waktu pemain masih dalam posisi bergerak.

4. Membiarkan bola memantul dengan gerak lengan, tanpa dibantu oleh kekuatan bahu.

5. Berat bdan tidak digerakkan sesuai dengan teknik dasar.

6. Hanya menggunakan kekuatan lengan dai bahu kebawah, tanpa mengikut sertakan kedua kaki.
Siku ditekuk sewaktu mengadakan kontak dengan bola. Tidak menekan kedua pergelangan tangan kebawah sehingga kedua lengan bawah tidak mempunyai kekuatan. Beberapa sekolah tidak memiliki fasilitas untuk pembelajaran pendidikan jasmani yang lengkap. Di daerah perkotaan yang padat penduduk untuk mencari lahan kosong sebagai tempat untuk mengajari anak-anak olahraga sepakbola sangat sulit dicari. Begitu pula sekolah yang terletak di pedesaan, peralatan seperti peluru, lembing, bola sepak, bola basket sangatlah minim dan sangat sulit untuk mencari pengganti apabila salah satu dari peralatan tersebut rusak karena terbatasnya tempat penjualan alat-alat olahragakreatifitas guru penjas yang sekiranya mau membantu memenuhi kebutuhan dalam proses pembelajarn. Untuk itu pengembangan sarana dalam pendidikan jasmanai sangatlah penting tujuannya adalah untuk memberdayakan anak dan memenuhi kebutuhan akan gerak pada anak dengan situasi yang dalam melakukan kegiatan petanque sehari-hari

\section{METODE}

Penelitian tindakan kelas ini dilaksanakan di kelas V SDN Teguhan 1 Ngawi. Pelaksanaan penelitian tindakan kelas ini telah dilaksanakan pada bulan Oktober 2019 dengtan menggunakan 1 siklus. Metode yang digunakan dalam penelitian ini adalah metode normatif survey. Metode normatif survey tidak dijelaskan dalam buku-buku penelitian yang tersirat oleh nama. Dalam metode ini kita harus menngunakan metode kepercayaan (Research Methods in Physical Activity, 2011: 288). Variabel penelitian yang dikaji adalah tingkat kemampuanteknik dasar permainan petanque siswa usia Dalam kabupaten ngawi tahub 2020. Populasi dalam penelitian ini adalah siswa usia 10-12 Sekolah Petanque perkotaan dan pedesaan tahun 2020 di Kabupaten Ngawi. Dimana 2 SP terletak di 
Perkotaan dan 11 SP yang terletak di pedesaan.

Cara pengambilan sampel yaitu dengan menggunakan Purposive Proporsional random sampling. Sampel dari SP perkotaan yaitu siswa SP Angicipi dan SP Modern, sedangkan siswa SP pedesaan yaitu SP Paron kids dan SP Mberan kids. Dari masing - masing SP tersebut kemudian diambil $40 \%$ dari total siswa pada tiap - tiap SP tersebut secara acak. Data dalam penelitian ini diperoleh melalui tes dan pengukuran kemampuan teknik dasar permainan petanque yang disusun berdasarkan validitas isi. Item tesnya terdiri dari komponen - komponen dasar teknik permainan petanque, yaitu :

1) Perkenalan terhadap bola, item tesnya adalah Tes melempar bola selama dan sebanyak mungkin agar bola mengenai bola lawan

2) Melempar bola (pointing), item tesnya adalah Tes melmpar bola lambung agar bola menjadi dekat dengan lawan

Petunjuk pelaksanaan tes dan pengukuran masing-masing teknik dasar permainan petanque terlampir. Data yang dikumpulkan pada setiap kegiatan observasi dari pelaksanaan siklus PTK dianalisis secara deskriptif kualitatif menggunakan teknik persentase untuk melihat kecenderungan yang terjadi dalam kegiatan pembelajaran.

1. Hasil ketrampilan passing bawah bolavoli dengan menganalisis nilai rata-rata passing bawah bolavoli dikategorikan dalam klarifikasi skor yang telah ditrentukan.
2. Sikap dan keaktifan peserta didik : dengan mengamati perilaku peserta didik pada saat pembelajaran passing bawah bolavoli berlangsung, kemudian dikategorikan dalam klasifikasi skor yang telah ditentukan.

3. Kognitif peserta didik: dengan jawaban peserta didik atas pertanyaan yang telah diberikan guru kemudian dikategorikan dalam klasifikasi skor yang telah ditentukan.

\section{HASIL DAN PEMBAHASAN \\ Penyusunan Norma}

Dalam Hasil dari analisis data hasil tes kemampuan teknik dasar Petanque ini. Selanjutnya melakukan analisis dengan menyusun norma klasifikasi tingkat kemampuan teknik dasar Petanque.

Adapun hasil pengklasifikasian dan penyusunan norma penilaian terhadap nilai total tingkat kemampuan teknik dasar permainan Petanque pada siswa usia diniantara SP perkotaan dan SP pedesaan Se -Kabupaten Ngawi Tahun 2020 yang dilakukan dalam penelitian ini adalah sebagai berikut :

Tabel 4.4 Norma Tingkat Kemampuan Teknik Dasar Permainan Petanque pada siswa usia 10 - 12 tahun antara SP perkotaan dan SP pedesaan Se -Kabupaten Ngawi Tahun 2020.

\begin{tabular}{|ccc|c|}
\hline & Interval & Kategori \\
\hline & $\geq$ & 356 & BS \\
\hline 333 & - & 444 & B \\
\hline 306 & - & 332 & C \\
\hline 278 & - & 305 & S \\
\hline 251 & - & 555 & K \\
\hline & $\leq$ & 250 & KS \\
\hline
\end{tabular}


Kemudian kemampuan total tingkat kemampuanteknik dasar permainan petanque pada siswa usia diniantara SP perkotaan dan $\mathrm{SP}$ pedesaan Se -Kabupaten Ngawi Tahun 2020 dicocokkan dengan hasil norma tersebut diatas. Hasil pencocokan dapat terlihat dalam diagram di bawah ini.

\section{Gambar 4.1 Diagram Data Hasil Tes Tingkat}

Kemampuan Teknik Dasar Permainan

Petanque pada siswa usia 10 - 12 tahun antara SP perkotaan dan SP pedesaan Se -Kabupaten Ngawi Tahun 2020

Dari hasil pencocokan antara norma yang telah dibuat dengan kemampuan tingkat kemampuan teknik dasar permainan Petanque pada siswa usia diniantara SP perkotaan dan SP pedesaan Se -Kabupaten Ngawi Tahun 2020, dapat dilihat bahwa dari anak yang memiliki kemampuan berkategori baik sekali yaitu sebesar 2 anak, kategori baik 15 anak, cukup 27 anak, sedang 7 anak, kurang 0 anak, kurang sekali 1 anak. Sedangkan 50 anak SP pedesaaan, anak yang memiliki kemampuan berkategori baik sekali yaitu sebesar 0 anak, kategori baik 0 anak, cukup 2 anak, sedang 24 anak, kurang 18 anak, kurang sekali 6 anak. Dari hasil tersebut di atas dapat disimpulkan di dalam sebagian besar kemampuan tingkat kemampuan teknik dasar permainan Petanque pada siswa usia dini SP perkotaan ialah berkategori cukup dan SP pedesaan ialah berkategori sedang.
1. Uji Perbedaan

\begin{tabular}{|c|c|c|c|c|}
\hline $\begin{array}{l}\text { Setelah } \\
\text { dilakukan } \\
\text { Tes Tingkat } \\
\text { Kemampuan } \\
\text { Teknik } \\
\text { Dasar } \\
\text { Permainan } \\
\text { Petanque } \\
\text { pada siswa } \\
\text { usia 10-12 } \\
\text { tahun antara } \\
\text { SP } \\
\text { perkotaan } \\
\text { dan SP } \\
\text { pedesaan Se } \\
\text {-Kabupaten } \\
\text { Ngawi } \\
\text { Tahun 2020, } \\
\text { kemudian } \\
\text { dilakukan } \\
\text { uji } \\
\text { perbedaan / } \\
\text { t-test. Uji } \\
\text { perbedaan } \\
\text { yang } \\
\text { dilakukan } \\
\text { dalam } \\
\text { penelitian } \\
\text { ini hasilnya } \\
\text { sebagai } \\
\text { berikut: } \\
\text { Perkotaan }\end{array}$ & 6 & 56,10 & 12,5568 & 2,447 \\
\hline Pedesaan & 6 & 43,73 & & \\
\hline
\end{tabular}

Berdasarkan hasil pengujian perbedaan dengan analisis statistik t-test Tingkat Kemampuan Teknik Dasar Permainan Petanque pada siswa usia 10 - 12 tahun antara SP perkotaan dan SP pedesaan Se -Kabupaten 
Ngawi Tahun 2020 diperoleh nilai sebesar 12,5568 dan $t_{\text {tabel }}$ dengan taraf signifikansi trjadi 5\% adalah sebesar 2,447. Hal ini menunjukkkan bahwa $t_{\text {hitung }}>t_{\text {tabel}}$, sehingga dapat disimpulkan bahwa antara hipotesis nol ditolak. Berdasarkan hasil tersebut menunjukkan bahwa Tingkat Kemampuan Teknik Dasar Permainan Petanque pada siswa antara SP perkotaan dan SP pedesaan Se Kabupaten Ngawi Tahun 2020 terdapat perbedaan yang signifikan. Dimana SP perkotaan memiliki tingkat kemampuan permainan petanque lebih baik di bandingkan SP pedesaan.

\section{PENUTUP}

\section{Simpulan}

Penelitian Tindakan Kelas yang dilakukan pada peserta didik kelas V SDN Teguhan 1 Ngawi dilaksanakan dalam dua siklus. Setiap siklus terdiri atas empat tahapan, yaitu: (1) perencanaan, (2) pelaksanaan tindakan, (3) observasi dan iterpretasi, dan (4) analisis dan refleksi. Hasil dari penelitian menunjukan bahwa penerapan model pembelajaran Penelitian Tindakan Kelas (PTK) dapat meningkatkan hasil belajar passing bawah bolavoli dari pra siklus ke siklus I dan dari siklus I ke siklus II . Dari analisisis data diperoleh hasil pada siklus I terjadi peningkatan hasil belajar passing bawah bolavoli untuk peserta didik yang tuntas yaitu $48,48 \%$ atau 16 peserta didik yang tuntas dari kondisi awal yaitu $21,21 \%$ atau 7 peserta didik yang tuntas dari jumlah 33 peserta didik .Sedangkan pada siklus II terjadi peningkatan hasil belajar passing bawah bolavoli sebesar $78,79 \%$ atau 26 peserta didik yang tuntas dari jumlah 33 peserta didik. Berdasarkan analisis data yang telah dilakukan diperoleh simpulan bahwa : Penerapan alat bantu pemelajaran dapat meningkatkan hasil belajar passing bawah bolavoli pada peserta didik kelas V SDN Teguhan 1 Ngawi Tahun Ajaran 2019.

\section{Saran}

Berdasarkan simpulan dan implikasi hasil penelitian yang dikemukakan di atas, peneliti menyampaikan beberapa saran untuk meningkatkan efektivitas pembelajaran Pesnjasorkes di kelas V SDN Teguhan 1 Ngawi

a. Guru hendaknya terus berusaha untuk meningkatkan kemampuannya dalam mengembangkan materi, menyampaikan materi, serta dalam mengelola kelas, sehingga kualitas pembelajaran yang dilakukannya dapat terus meningkat seiring dengan peningkatan kemampuan yang dimilikinya.

b. Guru hendaknya lebih inovatif dalam menerapkan alat bantu pembelajaran untuk mempermudah peserta didik menerima materi pembelajaran.

c. Guru hendaknya lebih sering melakukan inovasi terhadap alat bantu pembelajaran . Hal ini dapat membantu peserta didik dalam penerimaan materi.

d. Pembelajaran menggunakan penerapan alat bantu dalam pembelajaran Penjas dapat meningkatkan hasil belajar passing bawah bolavoli, guru hendaknya mencoba menggunakan alat bantu tersebut

e. Bagi peneliti akan lanjuti dengan penelitian-penelitian pada peserta didik lainnya, sehingga diperoleh pembelajaran yang sesuai dengan kemampuan peserta didik dan sesuai dengan perkembangan peserta didik di SD.

f. Perlu penyesuaian penerapan alat bantu pembelajaran dengan materi ajar peserta didik pada peneliti berikutnya.

g. Bagi peneliti berikutnya agar mau menindak lanjuti hasil temuan di lapangan seperti subjek penelitian dalam skala yang lebih luas dan menggunakan model penelitian baru dan lebih menyenangkan untuk meningkatkan hasil belajar peserta didik. 
DAFTAR PUSTAKA

Agus Kristiyanto. (2010a). Penelitian

Tindakan Kelas (PTK) Dalam

Pendidikan Jasmani dan

Kepelatiahan Olahraga. Surakarta:

UNS Press.

Agus Kristiyanto.(2010b). Memperluas Desain

Permainan Bola Voli di Masyarakat.

Surakarta : UNS Press.

Aunurrahman. (2009). Belajar dan

Pembelajaran. Bandung: CV. Alfabeta.

Dimyati dan Mudjiono.(2006). Belajar dan

Pembelajaran. Jakarta : Rineka Cipta.

Endang Komara.(2014). Belajar dan Pembelajaran Interaktif. Bandung : PT.Refika Aditama.

Giri Wiranto.(2016). Media Pembelajaran dalam Pendidikan Jasmani. Yogyakarta: Laksitas.

Imas Kurniasih dan Berlin Sani. (2015).Ragam Pengembangan Model pembelajaran: Kata Pena.

Nuril Ahmadi.(2007). Panduan Olahraga Bola Voli. ERA PUSTAKA UTAMA. 